\title{
LEWIS ACID-BASE TITRATIONS EMPLOYING MEGACYCLE-FREQUENCY OSCILLATORS
}

\author{
PAR\% II. TITIRATION INVOLVING STANNIC CHLOIRIDE IN ACETONITIRILE \\ AND BENZENE SOLUTION
}

ELDON T. HITCHCOCK* AND PHILIP J. ELVING

University of Michigan, Ann Arbor, Michigan (U.S.A.)

(Reccived Septumber 12 th, 1962 )

The objectives of the present investigation of the applicability of megacycle-frequency oscillators to the study of Lewis acid-base reactions and the investigation of the reaction of aluminum chloride with a group of nitrogen bases in the basic solvent acetonitrile (dielectric constant 36 ) have been described ${ }^{1}$. The present paper is concerned with the reaction of the Lewis acid, stannic chloride, with various Lewis bases in acetonitrile and in the inert solvent benzene (dielectric constant 2.3). Since benzene exhibits a weakly basic character (in the Lewis sense) toward Lewis acids as demonstrated by complexation with iodine ${ }^{2}$, silver ion ${ }^{3}$ and anhydrous aluminum halides ${ }^{4}$, it is classed as an inert solvent only with some qualification. However, its low diclectric constant does indicate that ionic dissociation will not be favored in it. Moreover, since the solvent benzene represents only slight competition for the acid, it is possible to study a much wider range of weak bases in this solvent.

In contrast to aluminum chloride (subl. $177.8^{\circ}$ ), stannic chloride is a low-boiling liquid with a greater covalent character (m.p. $-33^{\circ}$; b.p. II $\left.4 . I^{\circ}\right)$. While aluminum in monomeric aluminum chloride has an incomplete valence shell, the tin atom in stannic chloride has already attained the inert gas electronic configuration. On the basis of this difference in configuration, stannic chloride is expected to be a weaker Lewis acid than aluminum chloride; this has been verified experimentally5,0. However, unlike the case of aluminum chloride', titrations involving stannic chloride and nitrogen bases in acetonitrile gave no precipitate. Solutions of stannic chloride in acctonitrile werc easily prepared and standardized, and remained stable indefinitely.

Solnbility of stannic chloride in organic solvents. Owing to its covalent character, stannic cliloride is readily soluble in inert solvents such as hydrocarbons and halohydrocarbons. Little, if any, reaction seems to occur between it and benzene, as evidenced by the very small megacycle-freciuency response of benzene solutions of stannic chloride (ref. ${ }^{2}$ : Fig. 3) and the very small integral heat of dilution for stannic chloride in benzene? (see, however, the subsequent discussion under BASE STRENGTH CHARACTERISTIC). The appreciable solubility of stannic chloride in oxygen- or nitrogencontaining solvents is due to the basic character of the latter. No increase in megacycle-

* Present address: Colorado College, Colorado Springs, Colorado. 
frequency oscillator response occurs when stannic chloride is added to acetonitrile, in which it is readily soluble; this is likely due to the already high response to the solvent alone, which "drowns out" the response to the stannic chloride-acetonitrile reaction. Evidence for the reaction can be noted, however, by comparing the curves of Fig. I.

Conductivity studies indicate only a slight ionization of stannic chloride in thionyl chloride 8.0 . No evidence for dimcrization in any solvent could be found.

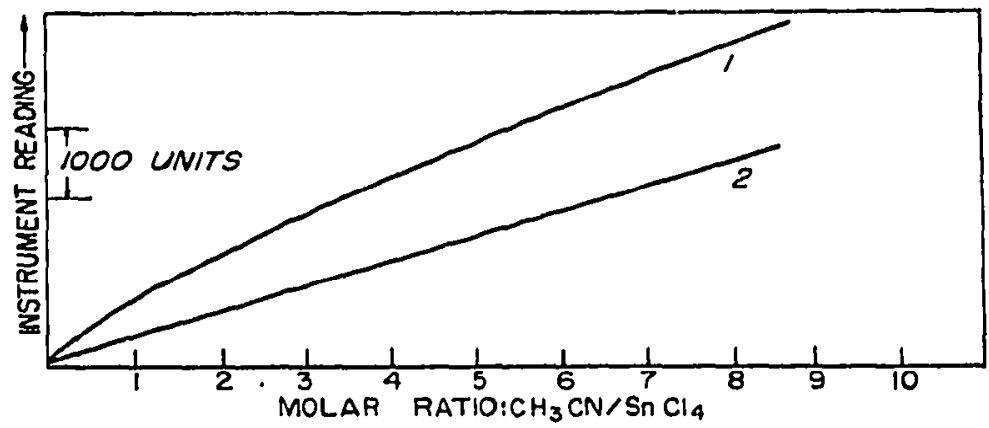

Fig. 1. Oscillator response on addition of acetonitrile to (1) $5.06 \mathrm{mmoles} \mathrm{SnCl} / 4$ in $100 \mathrm{ml}$ of benzene and (2) $100 \mathrm{ml}$ of ben $\% e n c$ alone. Compensator setting: 1500.

BEHAVIOIR IN ACETONTTRILE SOI.UTION

Table I summarizes the titration of nitrogen bases with stannic chloride; Fig. 2 gives typical titration curves. Unexpected were the definite inflections at molar ratios of approximately $A_{3} B_{4}$ and $A_{4} B_{3}$ for piperidine and $A_{4} B_{3}$ for pyridine; while these results

TABLE I

TITRATION OF NITIROGEN BASLS WITH STANNIC CHLORIDE IN ACTTONITRILT:

\begin{tabular}{|c|c|c|c|c|c|}
\hline \multicolumn{2}{|c|}{ Base present } & \multicolumn{2}{|c|}{$\begin{array}{c}\text { Volumic } 0.09 I 9 \\
S w C l_{4} \text { used }\end{array}$} & \multicolumn{2}{|c|}{$\begin{array}{c}\text { Molar ratio of } \\
\text { base : SnCl }\end{array}$} \\
\hline $\begin{array}{c}\text { Amount } \\
\text { lalicn } \\
\text { (mmoles) }\end{array}$ & $\begin{array}{l}\text { Coll } \\
\text { concn. } \\
(m M)\end{array}$ & $\begin{array}{c}\text { Break-x } \\
(m l)\end{array}$ & $\begin{array}{c}\text { Break-2 } \\
(m l)\end{array}$ & Break-I & Brualt-a \\
\hline \multicolumn{6}{|c|}{ Piperiline } \\
\hline 0.0505 & 0.505 & 0.42 & 0.70 & $1 \cdot 31$ & 0.79 \\
\hline $0.10 \mathrm{I}$ & 1.01 & $0.8 \mathrm{I}$ & 1.42 & 1.36 & 0.77 \\
\hline 0.101 & 1.01 & 0.82 & 1.40 & 1.34 & 0.78 \\
\hline 0.152 & 1.52 & 1.20 & 2.11 & $3 \cdot 3^{6}$ & 0.78 \\
\hline \multicolumn{6}{|c|}{ Pyridine } \\
\hline $\begin{array}{l}0.0557 \\
0.1 \times 15\end{array}$ & $\begin{array}{l}0.557 \\
1.115\end{array}$ & $\begin{array}{l}0.76 \\
1.50\end{array}$ & & $\begin{array}{l}0.80 \\
0.8 \mathrm{r}\end{array}$ & \\
\hline
\end{tabular}

are difficult to explain, they were none the less reproducible. Upon the addition of stannic chloride to diphenylamine, the instrument response increased continuously, leveling of at a molar ratio of about $x: 5$.

Table II summarizes the data for the reverse-order titrations, i.e., acid added to base; Fig. 3 gives typical titration curves. While both piperidine and pyridinegave 


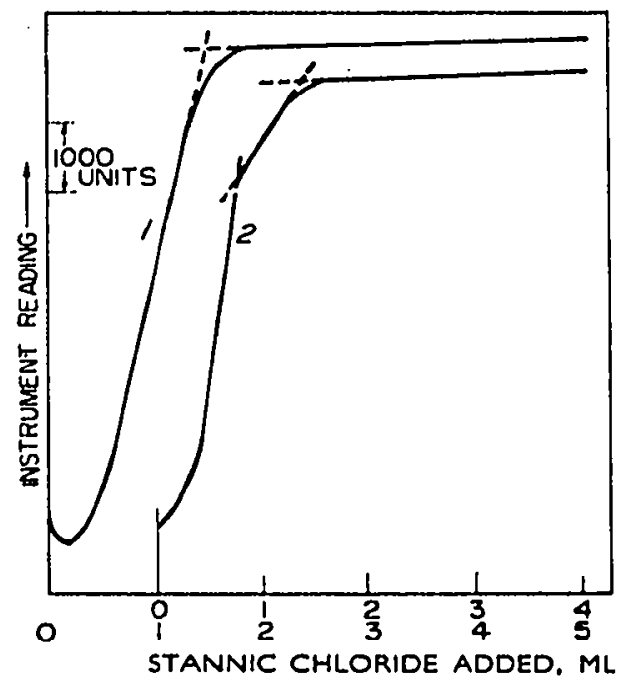

Fig. 2. Titration of $100 \mathrm{ml}$ of nitrogen base solution with $0.0919 \mathrm{M} \mathrm{SnCl}_{4}:$ (I) 0 . I I I5 mmole pyridine present: (2) 0.101 mmole piperidine. Solvent: acetonitrile: compensator setting: o.

TABLE II

TITRATION OF STANNIC CHLORIDE WITH NITROGEN BASES IN ACETONITRIRE

\begin{tabular}{|c|c|c|c|}
\hline \multicolumn{2}{|c|}{$S n C l_{4}$ present } & \multirow{2}{*}{\multicolumn{2}{|c|}{$\begin{array}{c}\text { Molar ratio of } \\
\text { Base : SnCl at curve }\end{array}$}} \\
\hline \multirow{2}{*}{$\begin{array}{l}\text { Amount } \\
\text { taken } \\
\text { (minoles) }\end{array}$} & \multirow{2}{*}{$\begin{array}{l}\text { Cell } \\
\text { concn. } \\
(\mathrm{mMI})\end{array}$} & & \\
\hline & & Maximum & Minimum \\
\hline \multicolumn{4}{|c|}{ Piperidine } \\
\hline 0.0459 & 0.459 & 1.16 & 2.87 \\
\hline 0.0910 & 0.919 & 1.10 & 3.11 \\
\hline 0.0919 & 0.919 & 1.08 & 3.43 \\
\hline \multicolumn{4}{|c|}{ Pyridine } \\
\hline $\begin{array}{l}0.0919 \\
0.1838\end{array}$ & $\begin{array}{l}0.919 \\
1.838\end{array}$ & $\begin{array}{l}1.07 \\
0.97\end{array}$ & \\
\hline
\end{tabular}

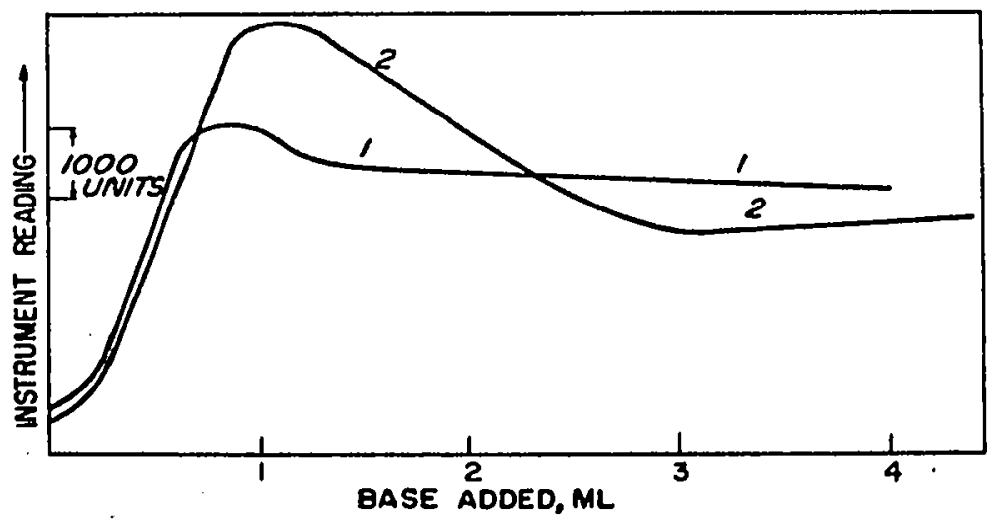

Fig. 3. Titration of $100 \mathrm{ml}$ of $0.000919 M \mathrm{SnCl}_{4}$ solution with (r) 0.1 I $15 M$ pyridine and (a) $0.10 \mathrm{I} M$ piperidine. Solvent: acetonitrile; compensator setting: 0 . 
maxima at very close to a I : I molar ratio, neither gave definite minima, e.g., the minima in the piperidine curves varied in three titrations between molar ratios of 2.7 and 3.4. In the case of pyridine the titration curve dropped immediately following the maximum and then continued in a straight line with slight negative slope. The curve for diphenylamine addition was very similar in shape to that for the reverseorder titration; no characteristic inflection was seen.

\section{BEHAVIOR IN BENZENE SOLUTION}

The megacycle-frequency oscillator response to reactions between Lewis acids and bases in a very low dielectric constant medium such as benzene, in which ionization is not expected to occur, should be due primarily to the polar character of the donoracceptor species formed, if the latter adduct is soluble in the solvent. Because of the very low instrument response to benzene itself, the instrument sensitivity may be greatly increased by the addition of series inductance ${ }^{1}$, permitting detection of the formation of such weak coordinate bonds as those in stannic chloride-ether com-

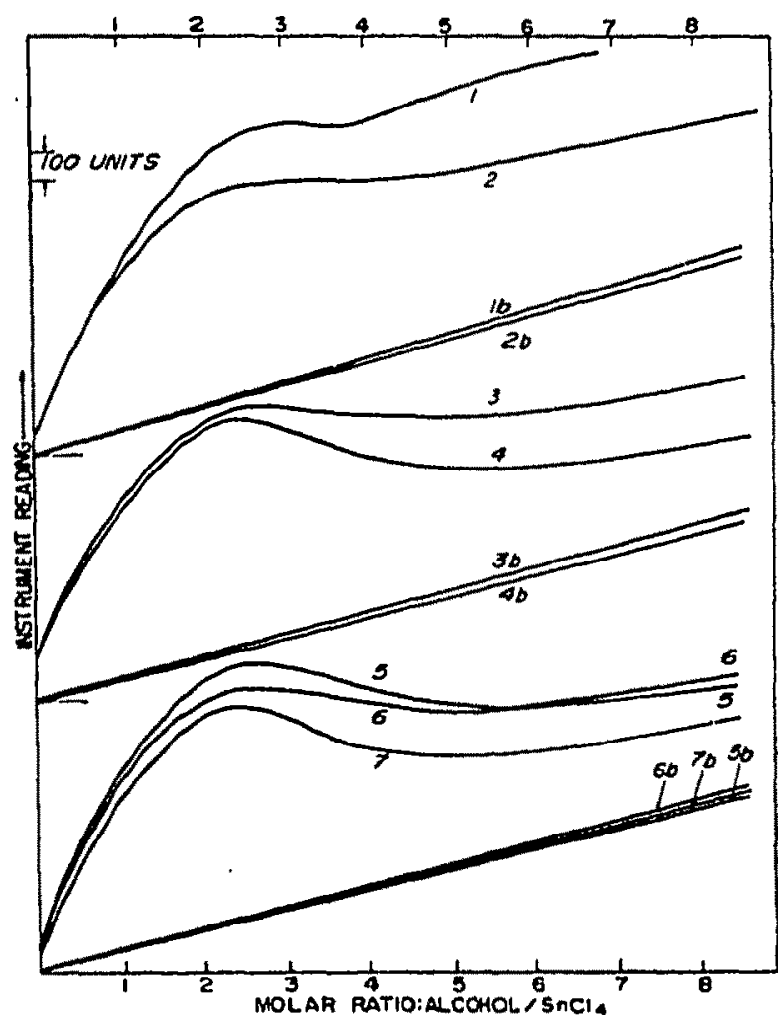

Fig. 4. Oscillator response on addition of purc


zene (curves marked only with numerals) and (b) $100 \mathrm{ml}$ of benzene alone (curves also marked with b). Compensator setting : 1500. I = methyl alcohol; 2 ethyl alcohol; $3=n$-propyl alcohol; $4=$ iso-propyl alcohol: $5=$ iso-butyl alcohol; $6=n$-butyl alcohol: $7 \Rightarrow$ sec.-butyl alcohol.

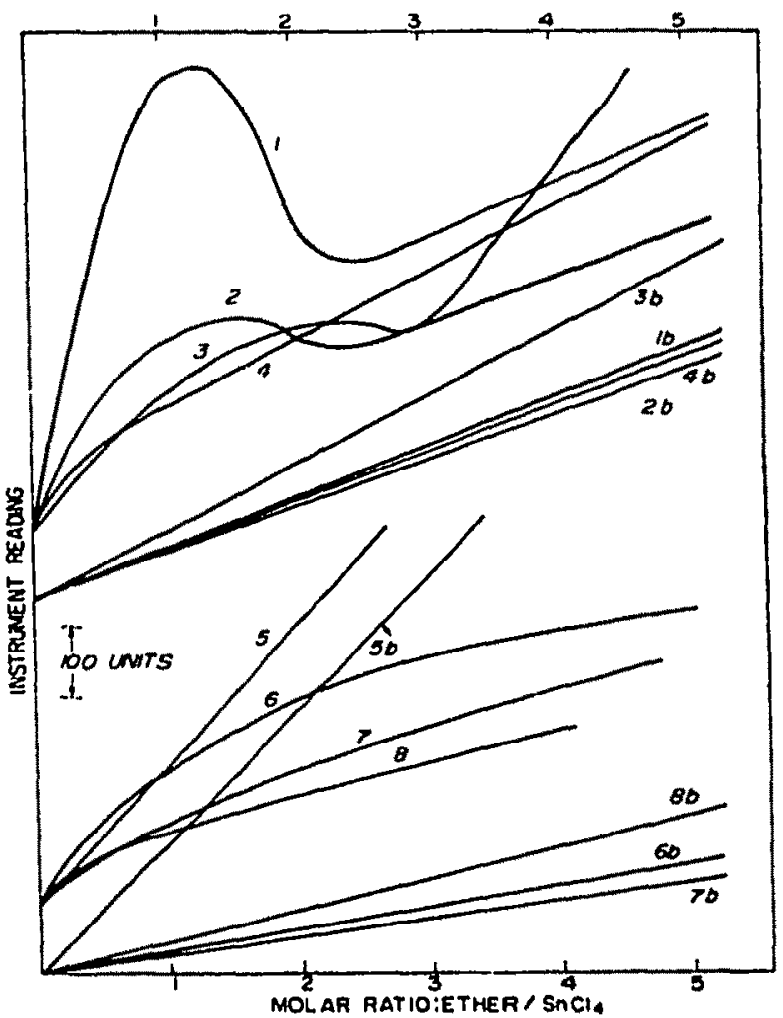

Iig. 5. Oscillator response on addition of pure ether to $(a) 5.0 \mathrm{mmoles} \mathrm{SnCl}_{4}$ in $100 \mathrm{ml}$ of benzene (curves marked only with numerals) and (b) $100 \mathrm{ml}$ of benzene alone (curves also marked with b). Compensator setting: $1500.1=$ tetrahydrofuran; $2=$ tetrahydropyran: $3=$ propylenc oxide; $4=$ cincole; $5 .=$ bis(2-chloroethyl) cther; $6=$ cthyl ether; $7 \Rightarrow n$-butyl ether; $8=$ iso-propyl cthcr. 
plexes. A compensator setting of 1500 was used for all of the studies in benzene. Titrations involving nitrogen bases. Titration of stannic chloride in benzene with pyridine, piperidine, $p$-toluidine and $n$-butylamine gave from the very beginning of the titration a precipitate which coated the cell walls and stirrer. The change in instrument response during titration was negligibly small with no significant inflection in the titration curve, suggesting that the adducts are highly insoluble. Addition of acetonitrile gave a positive response without a precipitate (Fig. I).

Titrations involving oxygen bases. The reaction between $0.05 M$ stannic chloride in benzene and oxygen bases such as alcohols, ethers, ketones and esters gave soluble products (with the exception of tert.-butyl alcohol and p-dioxane); the instrument response was related to the type and concentration of soluble complex formed.

All titration curves (Fig. 4) for the addition of pure alcohols (methyl, ethyl, npropyl, iso-propyl, n-butyl, sec.-butyl and iso-butyl) to stannic chloride show a maximum at the $A B_{2}$ molar ratio, followed by a broad minimum; finally, the curve runs parallel to the concentration response curve for the alcohol. The position of the minimum differs for each alcohol, ranging from a molar ratio of about $\mathrm{AB}_{\mathbf{3 . 5}}$ for methyl alcohol to $\mathrm{AB}_{6}$ for the propyl alcohols. No definite interpretation regarding stoichiometry seems possible from the minima, but the maxima, all at exactly $\mathrm{AB}_{2}$ molar ratio, indicate the formation of stable adducts of this composition.

In general, the curves obtained (Fig. 5) when cyclic ethers (tetrahydrofuran (THF), tetrahydropyran and propylene oxide) are added to stannic chloride, show a maximum, then decrease to a minimum, and finally increase in a straight line parallel to the concentration response curve for the ether involved. The general shape of the curve parallels that found for the low-frequency conductance titration of

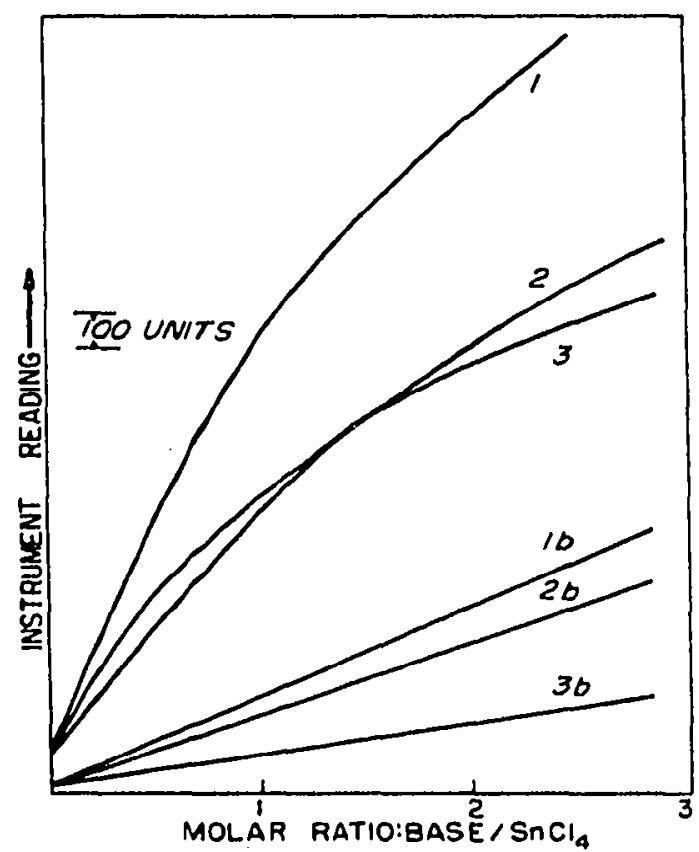

Fig. 6. Oscillator response on addition of pure oxygen base to $(a) 5.0 \mathrm{mmoles} \mathrm{SnCl}_{4}$ in $100 \mathrm{ml}$ of benzene (curves marked only with numerals) and $(b) 100 \mathrm{ml}$ of benzene alone (curves also marked with $b$ ). Compensator setting: 1500 . $I=$ cyclohexanone; $2=$ acctone: $3=$ ethyl acetate. 
stannic chloride with THF, in which the final increasing segment of the curve was ascribed to an ion-pair species, (THF) ${ }_{3} \mathrm{SnCl}_{3}+, \mathrm{Cl}-$, formed by the excess base ${ }^{10}$.

Noncyclic ethers (ethyl, bis(2-chloroethyl), iso-propyl and n-propyl), cineole, ketones (cyclohexanone and a.cetone), and ethyl acetate (Figs. 5 and 6) give a steadily increasing curve on addition to stannic chloride, which finally approaches a straight line similar to the concentration response curve of the oxygen base. While the positions of inflections do not indicate conclusively in all cases any definite stoichiometry, the magnitude of the response at the I : I molar ratio, for the ethers at least, is directly related to the base strength of the ether with respect to the stannic chloride molecule ( $c f$. subsequent discussion).

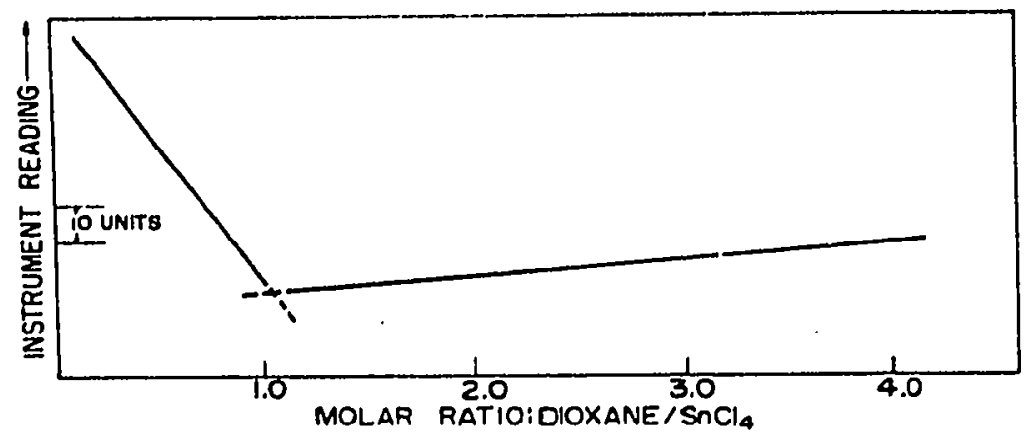

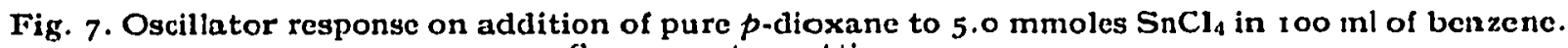
Compensator setting: 1500 .

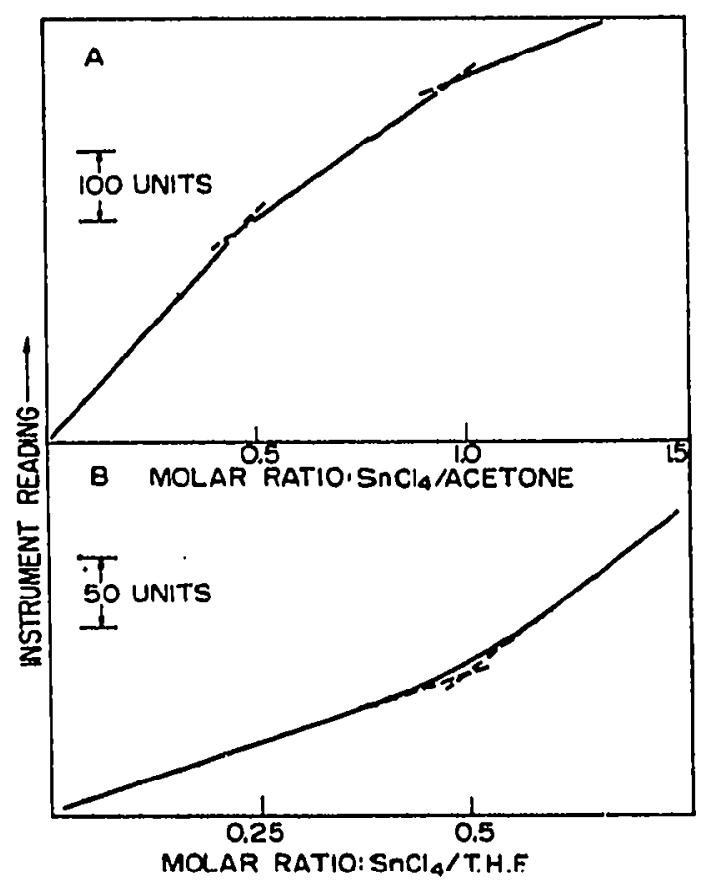

Fig. 8. Oscillator response on addition of $0.2025 M \mathrm{SnCl}_{4}$ to roo $\mathrm{ml}$ of solution containing $(A)$ 3.4 mmoles acetone and $(B) 2.03$ mmoles tetrahydrofuran. Solvent: benzene; compensator setting: i500. 
The addition of $p$-dioxane (Fig. 7) produces an immediate precipitate; the instrument response decreases linearly until the $I: I$ molar ratio is reached and then increases parallel to the straight-line concentration-response curve for $p$-dioxane, indicating that, after the stannic chloride has been precipitated, the response is only due to the increasing $p$-dioxane concentration. The molar ratio of $A B$ is in conformity with the behavior of dioxane as a diacid Lewis base ${ }^{9}$. The formation of a I : I stannic chloride-dioxane adduct has been ascribed to chelation with the dioxane being involved in a bidentate linkage with the tin, which would require conversion of the dioxane from its normal $Z$-form to a U-form ( $f f$. ref. $\left.{ }^{10}\right)$. It seems more probable that the adduct is of a more or less polymeric nature in which each dioxane molecule acts as a connecting link between two stannic chloride molecules. Polymer formation is supported by insolubility of the adduct, whereas a chelate complex would not be likely to be insoluble in benzene.

The instrument response increases continuously upon addition of $0.2 M$ stannic chloride to a benzene solution of each of the following oxygen bases: $E t_{2} \mathrm{O}$, iso- $\mathrm{Pr}_{2} \mathrm{O}$, THF, acetone and methyl ethyl ketone. However, significant inflections are seen only in the THF and acetone titration curves (Fig. 8), corresponding to formation of the $\mathrm{AB}_{2}$ complex for THF (no break is detected at the $\mathrm{I}: \mathrm{I}$ ratio) and at both the $\mathrm{AB}$ and $\mathrm{AB}_{2}$ molar ratios for acetone. The titration of $\mathrm{THF}$-acetone mixtures did not prove satisfactory for differentiating between the two bases. Addition of stannic chloride to $p$-dioxane in benzene gave no significant change in instrument response even when a fivefold excess was added.

\section{ISOLATION OF A BASE STRENGTH CHARACTERISTIC}

Basis of the approach. The use of a compensator, i.e., addition of series inductance, in connection with the oscillator has been discussed ${ }^{1}$. No series inductance was used for the studies in acetonitrile, but a setting of 1500 units was used for those in benzene. At this setting, the instrument response is linear with the dielectric constant of the cell contents (as long as there is no conductivity) for both the large cell used in the present work and the small cell which is also available; similar linearity has been observed by others ${ }^{21}$. The use of a high compensator setting also increases the sensitivity of instrument response.

Since the oscillator response varies linearly with the dielectric constant of the cell contents for nonconducting solutions and with the concentration of a polar compound in such soiutions, it may be assumed to a first approximation that the change in instrument response on titration of stannic chloride with a series of Lewis bases in benzene is due to formation of the coordinate covalent linkage of the adduct, and that all other factors in titrating a series of compounds essentially cancel. Consequent$l y$, one may represent the instrument response, $R$, for the Lewis acid-base reaction

$$
\mathbf{A}+: \mathbf{B} \rightarrow \mathbf{A}: \mathbf{B}
$$

as

$$
R=f\left(P_{A} C_{A t}, P_{B} C_{B C}, P_{\text {bond }} C_{x}\right)+R_{\text {molveas }}
$$

where $P_{A}$ and $P_{B}$ are the polarizabilities, and $C_{A \ell}$ and $C_{B t}$ the total concentrations of $A$ and $B$ in solution, and $P_{\text {bona }}$ is the polarizability of the polar bond and $C_{x}$ its concentration ( $f f$. ref.12 for detailed derivation).

In equation $2, \mathrm{f}\left(P_{\text {bond }} C_{x}\right)$ may be termed "bond response", $R_{\text {bond, and may be }}$ 
considered to be represented by the change in instrument response due to formation of the coordinate bond at concentration $C_{x}$. This response should be primarily a relative measure of the polarity of the coordinate bond formed and therefore a relative measure of the base strength (electron donor tendency) of a given Lewis base with respect to a given Lewis acid. Solving equation 2, for "bond response",

$$
\begin{aligned}
R_{\text {bona }} & =\mathrm{f}\left(P_{\text {bona }} C_{x}\right)=R-\mathrm{f}\left(P_{A} C_{A \ell} P_{H} C_{\boldsymbol{D}}\right)-R_{\text {molvent }} \\
& =R-R_{A}-R_{\Delta}-R_{\text {molvent }}
\end{aligned}
$$

where $R_{A}$ and $R_{B}$ are the experimentally determined instrument responses to frec $A$ and $B$, respectively, at concentration $C_{x}$.

A typical experimental situation is shown in Fig. 9 . Line $A B$ is the concentration

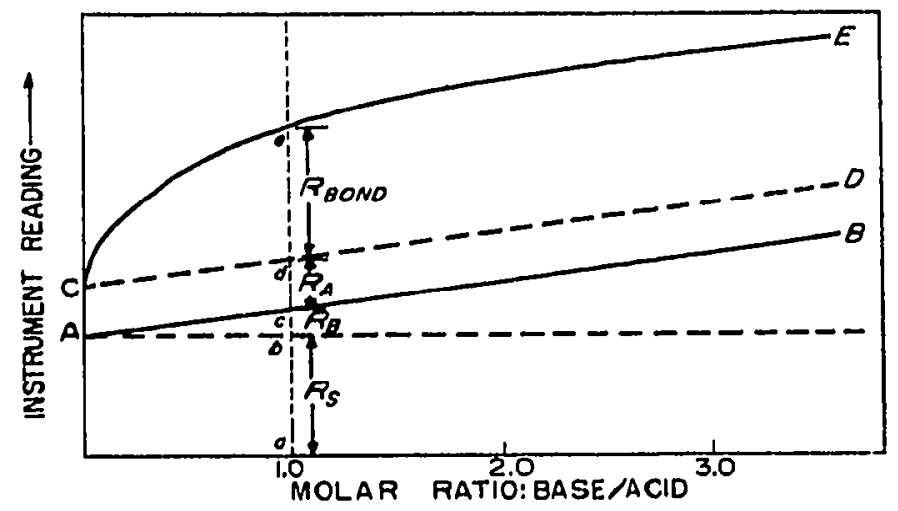

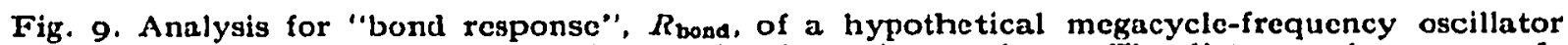
response curve for Lewis acid-base interaction in an inert solvent. The distance ab corresponds to the response due to solvent alone, $b c$ and $c d$ to the responses due to presence of base and acid, respectively, at a given concentration (molar ratio $=1 ; \mathbf{r}$ ), and de to the response duc to interaction of the base with the acid at the given concentration.

response for the Lewis base; distance $A C$ corresponds to the response due to the addition of a given amount of Lewis acid to the solvent alone (making concentration $\left.C_{x}\right) ; C E$ is the response obtained upon continuous addition of base to the acid solution. At the I : I molar ratio, $a b, b c, c d$ and $d e$ are the respective responses of the solvent, $R$, the base added, $R_{B}$, the acid added, $R_{A}$, and the "bond response",

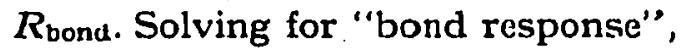

$$
R_{\text {bond }}=\| c=a c-a l t
$$

Assuming that the "bond response" is a measure of the base strength of 13 with respect to $A$, a simple and rapid method of compiring base strengths relative to a given Lewis acid is thus available.

In the present derivation, no allowance has becn made for interaction between components and solvent. Although inert solvents such as benzene are quite unreactive, there is evidence that some slight association does occur between benzene and stannic chloride based on the instrument response observed in this study, when stannic chloride is added to benzene. The response is much greater than would be predicted trom the dielectric constant of pure stannic chloride $(2.87), e . g .$, the ditterence in response between roo $\mathrm{ml}$ of $0.05 M$ stannic chloride in benzene and roo $\mathrm{ml}$ of pure 
benzene is approximately roo instrument units, while the increase in response due to the presence of an equal amount of diethyl ether (dielectric constant 4.33 ) in benzene is only 26 units. Such a result is not surprising; it merely verifies the belief that benzene can behave as a Lewis base and coordinate with an acid2,3,13. Addition of a base which is considerably stronger than benzene, is likely to cause a partial displacement of solvent with a corresponding decrease in the response due to the Lewis acid-solvent association. It can not be assumed, however, that this contribution falls to zero. Since it was not known how much to allow for the decrease in acidsolvent response, the full roo instrument units were used in the present study as the response due to the $0.05 M$ stannic chloride in benzene regardless of the oxygen bise added. Since this procedure was used in every case, the relative values obtained for the basicities of the various oxygen bases should not be greatly affected. (The ultraviolet absorption observed when stannic chloride is dissolved in toluene has been considcred as due to a charge transfer process of the type described by MULLIKEN ${ }^{3}$.)

Correlation with other base strength measurements. The megacycle-frequency "boncl response", Rbond, at I : I molar ratios and at a concentration of $0.05 M$, for the complexes formed between stannic chloride and the series of oxygen bases investigated are compared in Table III and Fig. ro with the data obtained for these compounds by other methods for measuring relative base strength.

No relationship is seen to exist between dielectric constant and base strength, a fact which has been previously noted 14.15 .

The lack of good correlation between "bond response" and heat of mixing" is

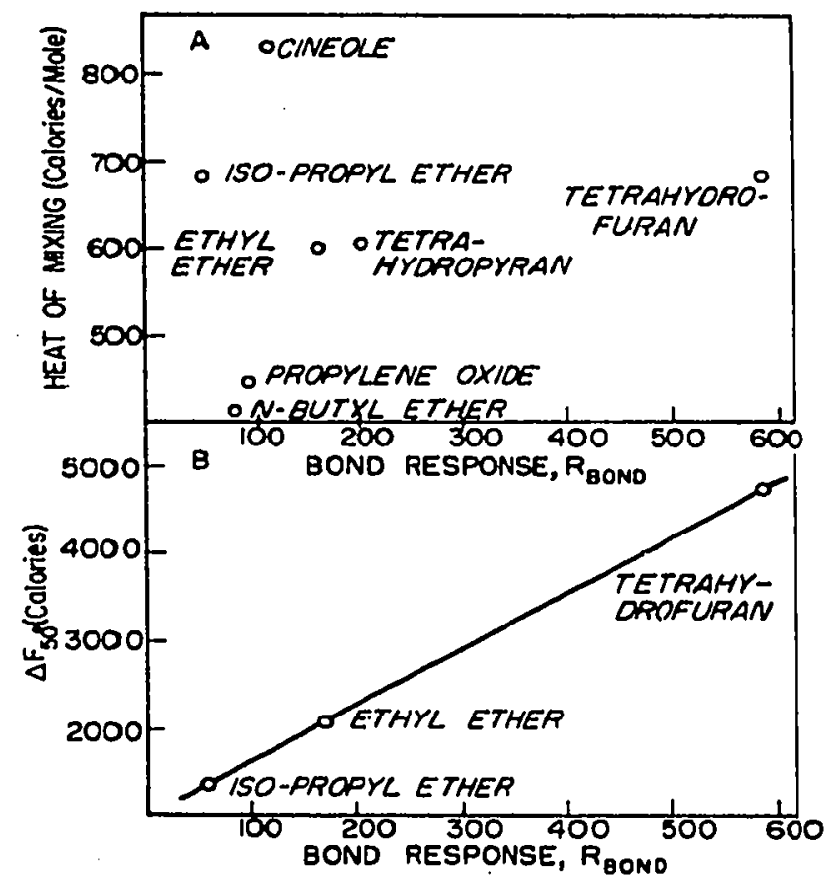

Fig. 10. Correlation of the megacycle-frequency oscillator response in instrument units duc to interaction of $\mathrm{SnCl}_{4}$ and ethers in benzene (both $0.05 M$ ) with other base strength data for cthers: $(A)$ heat of mixing with chloroform (calories/mole) $10 ;(B)$ molar frec energy of dissociation for the complex $\mathrm{R}_{\mathrm{g}} \mathrm{O}: \mathrm{BF}_{\mathrm{s}} 17$. 


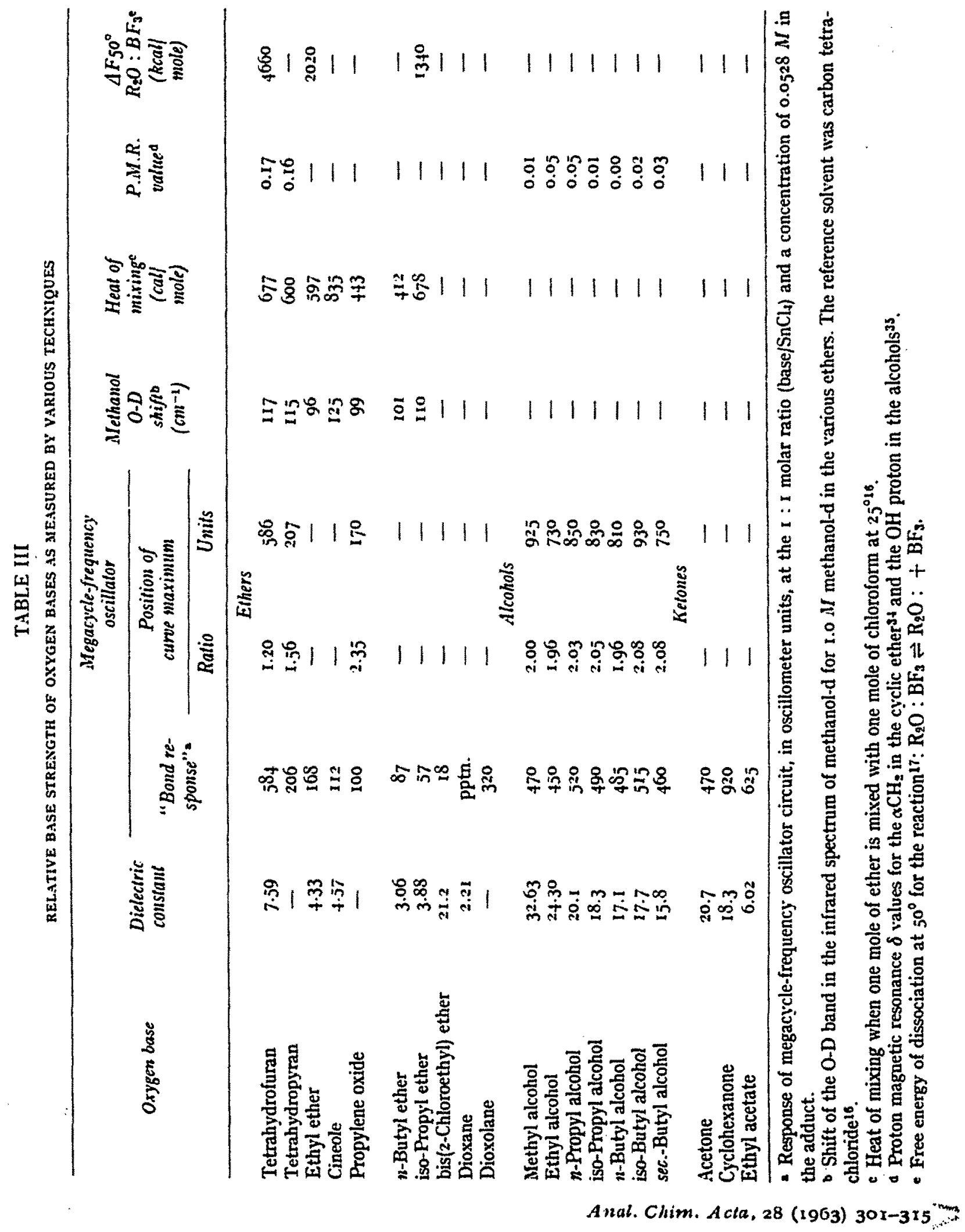


believed to be primarily due to the difference in steric nature of the two reactions being compared. For heat of mixing, the reaction involves hydrogen bonding of the chloroform hydrogen to the ether donor oxygen; the reaction in the present study involves a much larger acceptor, the stannic chloride molecule. (It must be remembered that stannic chloride is a relatively large molecule compared to the Lewis acids used in some of the reported studies on base strength.) The effects of the steric factors discussed by BROWN et al.17-20 are significant to the present comparison and may well account for some or all of the deviation from linearity in Fig. IoA. In general, the orders of base strength for the seven ethers agree except for iso-propyl ether and cineole.

Cineole may be considered a methyl-substituted tetrahydropyran with a dimethylene bridge between carbon atoms 2 and 5 :

$$
\text { [1] }
$$

Tetrahydropyran



Cineole

Owing to the inductive effect of the methyl groups, the oxygen in cineole should have a greater electron density than the oxygen in tetrahydropyran and, consequently, greater intrinsic base strength. This is verified by the greater molar heat of mixing with chloroform. However, the apparent reverse order of basicity with respect to stannic chloride likely results from stcric hindrance to the approach of the large stannic chloride molecule to the cineole oxygen; the steric strain involved in forming the complex is more effective than the increased electron density of the donor oxygen; this type of strain is virtually nonexistent in hydrogen-bonding reactions because of the small size of the hydrogen atom.

It is apparent from Fisher-Hirschfelder-Taylor models of the ethers that the greater shielding of the donor oxygen by neighboring methyl groups in cineole and iso-propyl ether would hinder the approach of the relatively large stannic chloride molecule and thus decrease the apparent base strength of these ethers with respect to stannic chloride. The reversal in base strength of ethyl ether and iso-propyl ether is thus explicable.

When the steric effects are comparable, differences in inductive effect will be evident, e.g., ethyl ether is more basic with respect to stannic chloride than bis(2chloroethyl) ether as expected on the basis of the inductive effect alone.

The correlation of "bond response" with the free energy of dissociation for the complexes formed in the reaction of ethers with $\mathrm{BF}_{3}{ }^{17}$ is very good (Fig. IoB). This reaction should more closely parallel the stannic chloride-ether interaction with regard to steric factors, since the two Leivis acids are comparable in size.

Reported measurements on relative base strengths of alcohols are relatively rare, probably owing to their self-association in the liquid state, which complicates the interpretation of data on experiments involving the liquid alcohols. However, the effect of self-association should be less pronounced at high dilution in an inert solvent; consequently, the results obtained by the present technique should not be seriously affected by self-association.

\section{DISCUSSION}

The present studies, of which this is the second, have explored the utility of megacycle- 
frequency oscillators for following Lewis acid-base reactions in solution from the viewpoints of $(a)$ the quantitative titrimetric determination of Lewis acids and bases, (b) the evaluation of the stoichiometry of their reactions, and (c) the measurement of relative base strength of Lewis bases with respect to a given Lewis acid.

The titrimetric and stoichiometric problems have been examined in this and the previous paper'. Titration of stannic chloride with Lewis bases in oxychlorides of phospliorus, sulfur and selenium, benzene and other solvents, using thermometric, cryoscopic, conductometric, potentiometric and indicator end-point determination has been described7,8,10,15,21-25. In the present study, nitrogen bases in acetonitrile as solvent have been successfully titrated with the Lewis acids, aluminum chloride and stannic chloride, with an error in accuracy ranging from 0.5 to $4 \%$; reverse-order titrations are equally successful. Reaction of stannic chloride with oxygen bases such as tetrahydrofuran and dioxane in benzene solution permit titrations of comparable accuracy. While the latter accuracy is considerably less than that possible in conventional protonic acicl-base titrations in aqueous and nonaqueous media, it compares favorably with that attainable with other techniques used to follow Lewis acid-base reactions in solution. An added advantage is that the characteristic response of the megacycle-frequency oscillator circuit to coordinate bond formation in inert solvents permits reactions to be followed even when solution conductivity is virtually nil.

The characteristic shapes of the titration curves obtained (positions of maxima, minima and other inflections) give information regarding the species forming during the course of the reaction. The information thus obtained on the stoichiometry of the stannic chloricle adducts with Lewis bases is subsequently cliscussed.

In addition, the megacycle-frequency oscillator may be applicable to the study of the relative base strengths of weak bases toward Lewis acids. Introduction of appropriate series inductance into the oscillator circuit makes the instrument response linear to the diclectric constant of the cell contents. As an ether is added to stannic chloride in benzene, the instrument response increascs owing to the formation of the new coordinate bond. When the molar ratio is $I: I$, the response is considered to be dircctly related to the polarity of the coordinate bond formed and thereforc a measure of the base strength of the ether with respect to stannic chloride. Consequently, by analysis of their titration curves, a series of ethers have becn arranged in order of base strength toward stannic chloride in benzene as solvent. Agreement of these data with the limited existing data on relative base strength is quite satisfactory when comparable steric factors are involved.

Complexation of stannicchloride zeithnitrogen and oxygen bases. Addition of compounds possessing sufficiently strong donor groups to stannic chloride (purc or in solution) causes a reaction, in which tin usually increases its coordination number to $\operatorname{six} 8,24,20-30$.

Unlike the transitional clements showing a coordination number of six, the tin atom already has its underlying $d$-orbitals filled. When tin exhibits a coordination number greater than four, the $d$-orbitals of the valence shell of tin must be utilized ${ }^{31}$. It the outer $d$-orbitals are used, the coordination number of six must be attained through $s p^{3} d^{2}$ hybridization, giving the symmetrical octahedral configuration with the valence bonds clirected toward the six corners of a regular octahedron. The formation of 2 : I adducts between alcohols and stannic chloride in benzene is clearly evident from their titration curves.

Formation of stannic chloride complexes, in which the ligand: $\mathrm{SnCl}_{4}$ ratio is

Anal. Chim. Acta, 28 (1963) 301-315 
different from $2: I$, has been reported 24,24,27. Usually it can be shown either that such complexes ionize or that the solvent becomes involved in the complex and, consequently, the coordination number of six is still maintained for tin, e.g., stannic chloride trihydrate ${ }^{20},\left[\mathrm{SnCl}_{3} \cdot\left(\mathrm{H}_{2} \mathrm{O}\right)_{3}\right]+\mathrm{Cl}^{-}$or $\left[\mathrm{H}_{2} \mathrm{O} \cdot \mathrm{SnCl}_{4} \cdot \mathrm{OH}\right]-\mathrm{H}_{3} \mathrm{O}+$, and the I : I triethylamine-stannic chloride complex in thionyl chloride ${ }^{24},\left[\left(\mathrm{C}_{2} \mathrm{H}_{5}\right)_{3} \mathrm{NSOCl}\right] \cdot$ $\mathrm{SOCl} \cdot \mathrm{SnCl}_{6}$.

Formation in acetonitrile of $I$ : I complexes between stannic chloride and nitrogen bases is indicated in the present investigation since maxima occur in the megacyclefrequency titration curves at this ratio. The complexes likely contain a solvent molecule as a second added ligand, thus giving tin a coordination number of 6 .

In benzene, formation of a I : I complex with stannic chloride seems to be indicated for some of the ethers studied. Since benzene is not expected to take part in the complexation, the possibility of pentacoordinate tin in these complexes has to be considered. Such complexes would involve $s p^{3} d$ hybridization of the tin orbitals giving a bipyramidal configuration. While such configurations are rare, other experimental evidence points to this configuration for certain tin complexes, e.g., WoOLF ${ }^{32}$ has prepared I : I complexes of stannic fluoride with trimethylamine, dioxane and tetrahydrofuran, and LAUBENGAYER AND $\mathrm{SMITH}^{29}$ have shown that the $2:$ I ethanolstannic chloride adduct splits off hydrogen chloride giving $\left(\mathrm{C}_{2} \mathrm{H}_{3} \mathrm{OH}\right)\left(\mathrm{C}_{2} \mathrm{H}_{5} \mathrm{O}\right) \mathrm{SnCl}_{3}$, which may involve pentacoordinate tin.

The preparation and characterization of solid adducts of stannic chloride and various oxygen bases will be described in a subsequent paper ${ }^{33}$.

\section{EXPERIMENTAL}

General experimental details have been described.

\section{Chenicals}

Stannic chloride solutions, $0.1 M$ in acetonitrile and $0.2 M$ in benzene, were prepared by pipetting the necessary amount of anhydrous $\mathrm{SnCl}_{4}$ into the anhydrous solvent and then standardized by adding a $2.0-\mathrm{ml}$ aliquot to $50 \mathrm{ml}$ of methyl alcohol and $1.0 \mathrm{ml}$ of $5 M$ nitric acid, and titrating the chloride potentiometrically with $0.1 M$ silver nitrate. The benzene solution was stored in automatic burets equipped with drying tubes.

The following reagent-grade ethers were purified by refluxing with lithium aluminum hydricle and distilling through a 24-inch Fenske column: ethyl ether, iso-propyl ether, $n$-butyl ether, bis(2-chloroethyl) ether, tetrahydrofuran and tetrahydropyran. Dioxane (Eastman Kodak white label) and cineole (yellow label) were distilled from sudium metal through the same column. Purified propylene oxide was kindly supplied by Sister Mary Brandon Hudson. All ethers were distilled out of contact with air and were stored under nitrogen in glass-stoppered bottles in the dark at $7^{\circ}$; they were used only after a negative test for peroxicle.

\section{Titration procedures in benzene}

Approximately $75 \mathrm{ml}$ of anhydrous benzene was placed in the megacycle-frequency titration cell, followed by $25.00 \mathrm{ml}$ of $0.2 M$ stannic chloride in benzene. The cell cap was quickly put in place, the flushing gas (nitrogen) allowed to flow into the upper space of the titration cell, and the stirrer started. After the initial instrument reading, 
the pure oxygen base was added in ca. 0.06 to $0.10-\mathrm{ml}$ increments. Instrument-reading stability was attained in a matter of seconds, after which the reading was noted. The base was added until a molar ratio (base/ $\mathrm{SnCl}_{4}$ ) of about $5:$ I was reached. No correction for dilution was applied to the instrument reading, since a total of not more than 2 or $3 \mathrm{ml}$ of base was added.

In carrying out the reverse titrations (base with stannic chloride), much larger volumes of titrant were used, and the usual corrections for dilution were applied when necessary.

The authors wish to thank the U. S. Atomic Energy Commission, which helped support the work described. One author (E.T.H.) also wishes to thank the Standard Oil Company of Ohio for a fellowship.

\section{SUMMARY}

J3y using a megacycle-frequency oscillator to follow the reaction, the Lewis acid, stannic chloride, can be titrated with nitrogen bases in acctonitrile as solvent and with oxygen bases in benzene as solvent with an error of $0.5-4 \%$; reverge-order titrations were equally successful.

The characteristic maxima and ininima in the titration curves indicate that in acetonitrile stannic chloride probably forms $\Lambda \mathrm{B}, \mathrm{A}_{9} \mathrm{~B}_{4}$ and $\Lambda_{4} B_{3}$ adducts with piperidine, and $A B$ and $\Lambda_{4} B_{3}$ adducts with pyridine; no adduct was indicated for diphenylamine. In benzene solution, stannic


iso- $\mathrm{B} \| \mathrm{OH},(b) \Lambda \mathrm{B}$ and $\Lambda \mathrm{B}_{2}$ adducts with acetone and tetrahydrofuran, and $(c)$ an $A B$ adduct with dioxane; the stoichiometry for a group of ethers is less decisive. The presence of the $1:$ I tetrahydrofuran-stannic chloride adduct in benzene supports the belief that pentacoordinate tin exists in certain adducts with oxygen bases.

The megacycle-frequency oscillator was also applied to the estimation of the relative base strength of Lewis bases toward a given Lewis acid by assuming that the instrument response increase, as an ether or alcohol was added to stannic chloride in benzene, is due to the formation of the new coordinate bond. Agreement of the data obtained with the limited existing data on relative base strengths of ethers is good in those cases where comparable steric factors are involved.

\section{RESUME}

Les auteirs ont effectué le titrnge de l'acide de Lewis, $\mathrm{SnCl}_{4}$, a l'aide de bases azotécs, dans l'acétonitrile (comme solvant) et de bases oxygénées dans le benzene, en utilisant un oscillateur à fréquences de l'ordre du mégacycle. Un tel oscillateur a également été appliqué à la détermination de la force relativo de bases de Lewis, par rapport à un acide de Lewis donné.

\section{ZUSAMMENFASSUNG}

Beschreibung einer Methode zur Titration von Lewissalure $\left(\mathrm{SnCl}_{4}\right)$ mit Stickstoffbasen und Saucrstoffbasen unter Verwendung eines Hochifrequenzoscillators. Das Verfahren cignet sich auch zur Feststellung der Basizitat einer Lewisbase gegenüber einer gegebenen Lewissäure.

\section{REFERENCES}

1 E. T. Fitchcock And 1. J. Elving, Anal. Chim. Atta, 27 (1902) 501 .

2 R. S. MULLikeN, J. Am. Chem. Soc., 72 (1950) 600.

3 R. S. Mulliken, J. Am. Chem. Soc., 74 (1952) 811 .

4 D. D. ELEY AND P. J. King, Trans. Faraday Soc., 47 (1951) 1287.

S O. C. DERMER, D. M. Wilson, F. M. JOHNSON AND V. HI. Diermer, J. A m. Chem.Suc., G3 (1941) 2881 .

- D. H $\Lambda$ WKe ANd J. Steigman, Anal. Chem., 26 (1954) 1989.

7. T. Zenchlesky. J. Preriale and J. C. Cobi, Anal. Chem., 28 (1956) 67.

a. Garber. L. Prast and W. F. Luder, Anal. Chein., 25 (1953) 581.

- I. M. Tol Thorp in I. M. Kolthorr AND P. J. Elving, Treatise on Analytical Chemistry, Paxt I, Vol. I, Interscience, New York, p. 405-421.

20 S. T. Zenchelsky and P. R. Segatto, J. Am. Chem. Soc., 80 (1958) 4796.

21 P. H. SHERRICK, G. A. DAWE, R. KARR AND E. F. EWJi, Mantchl of Chemical Oscillometry, E. H. Sargent it Co., Chicago, 1954 . 
12 E. T. Hirchcock, Ph.D. Thesis, The University of Michigan, r96r.

13 L. J. Andrews AND R. M. Keerzr, $J$. Am. Chem. Soc, 71 (1949) 3644.

14 M. H. DILKe, D. D. Eley AND M. G. Sheppard, Trans. Faraday Soc., $46(1950) 26 \mathrm{t}$.

15 W. Gordy and S. C. Stakford, $J$. Chem. Phys., 8 (1940) 170.

10 S. Searles and M. Tamres, $J$. Am. Chem. Soc., 73 (1951) 3704.

17 H. C. Brown and R. M. ADAMs, $f$ : Am. Chem. Soc. 64 (1942) 2557 .

i* H. C. Brown, H. J. BARtholomax AND M. D. TAYzor, J. Am. Chem. Soc., 66 (x944) 435.

1. H. C. Brown and M. Gerstern, $J$. Am. Chem. Soc., 72 (1950) 2926.

20 H. C. Brown, H. I. Schlesinger and S. J. Cardon, J. Am. Chem. Soc., 04 (1942) 325.

21 V. Gutmann, Z. Anorg. Allgem. Chem. 270 (1952) 179.

22 W. S. Peterson, C. J. Heimerzheim and G. B. L. Smith, J. Am. Chem. Soc..65 (1943) 2403

23 H. Spanda and E. Brunneck, $Z$, Anorg. Allgem. Chem., 270 (1952) 201.

24 H. Spanda and E. Brunneck, $Z$. Anorg. Allgem. Chem., 278 (1955) 197.

28 M. Usanovich, T. Sumarokova and Y. Nevskaya, Dokl. Akad. Nauk SSSR, 98 (1954) 617.

20 'T. R. E. DeVlin AND D. C. PePper in P. H. Plesch, ed., Cationic Polymerization and Related Complexes, Academic Press, New York, 1953, p. 24-27.

27 V. Gutmann, Monatsh. Chem. 85 (1954) 393. 404.

28 W. HIEBER AND E. REINDL, Z. Elektrochem., 40 (1940) 559.

20 A. W. Laubengayer and W. C. Smith, J. Am. Chem. Soc., 76 (1954) 5985.

so H. H. Sisler, H. H. Batey, B. Prahler AND R. Mattaik, J. Am. Chem. Soc., 70 (r948) 3821,

3) R. N. KELLER AND R. W. PARRY in J. C. BAILER, ed., The Chemistry of Coordination Compounds, Reinhold, New York, 1956, p. 167.

32 A. A. Wools, J. Inorg. \& Nual. Chem., 3 (1956) 285.

33 E. T. Hitchcock AND P. J. Elving, Anal. Chim. Acta, to be published.

34 H. S. Gutowsky, R. I. Rutledge, M. Tamres and S. Searles, $J$. Am. Chem. Sor.. 76 (r954) 4242 .

36 L. H. Meyer, A. Sarka and H. S. Gutowsky, f, Am. Chem. Soc., 75 (1953) 4567.

Anal. Chim. Acta, $28(\mathrm{rg} 63) 30 \times-315$ 